\title{
Study of the phytoestrogen content of goat's rue (Galega orientalis), alfalfa (Medicago sativa) and white clover (Trifolium repens)
}

\author{
HanNu SAloniemi, KaARlo Kallela and IlKKa SaAstamoinen
}

\begin{abstract}
Saloniemi, H., Kallela, K. \& Saastamoinen, I. 1993. Study of the phytoestrogen content of goat's rue (Galega orientalis), alfalfa (Medicago sativa) and white clover (Trifolium repens). Agric. Sci. Finl. 2: 517-524. (College of Veterinary Medicine, Dept. Basic Veterinary Medicine, Sect. Animal Hygiene, FIN-00581 Helsinki, Finland.)

Studies were conducted to determine the phytoestrogen content of goat's rue (Galega orientalis $\mathrm{Lam}$.), alfalfa (Medicago sativa $\mathrm{L}$.) and white clover (Trifolium repens $\mathrm{L}$.), all belonging to the Fabaceae family subjected to test cultivation at research stations of the Agricultural Research Centre of Finland. Apart from some insignificant quantities, goat's rue did not contain any known phytoestrogens. Even in biological studies it had no estrogenic effect. The estrogenic effect of alfalfa was apparently due to coumestrol, which was discovered in the samples in quantities of 34-65 ppm. All white clover varieties contained very small quantities of estrogenic isoflavones and coumestrol, and they did not explain the increased weight of the immature rat uterus observed in the biological studies.
\end{abstract}

Key words: phytoestrogens, goat's rue, alfalfa, white clover

\section{Introduction}

Studies of the effects of phytoestrogens have been conducted since the early 1940 s as a result of widely spread fertility problems observed in Australian sheep (BENNETTS et al. 1946). In Finland these studies started in the 1960s. Their aim was primarily to determine whether phytoestrogens were involved in the fertility disorders in cows which occurred commonly especially in the spring at the beginning of the grazing season (KALLELA 1964). Interest in phytoestrogens has generally been aroused by their adverse properties. They may, however, also be beneficial while increasing the growth rate of animals and the milk yield of cows (REFSDAL 1976, PETTERSON et al. 1984). According to recent studies, they may also have a prophylactic effect against some hormone-related human malignancies (ADLERCREUTZ et al. 1991, Rose 1992).
The known phytoestrogens are either isoflavonoids or coumarines. Of the isoflavonoids, biochanin-A and genistein, which in monogastric animals have an estrogenic effect, are broken down in the rumen of ruminants into inactive paraethylphenol (PETTERSSON et al. 1984). Two other phytoestrogens, daidzein and formononetin, are converted by ruminal microbia into active equol. Coumestrol, which belongs to coumarins, is absorbed and is active as such (PETTERSSON et al. 1984).

Many Finnish fodder and pasture plants contain small amounts of phytoestrogens. The highest concentrations of phytoestrogens occur in red clover, so that all varieties of red clover contain phytoestrogens. Abundant feeding of a diet based on red clover silage has been shown to cause fertility problems in cattle (KALLELA et al. 1984).

Despite its numerous good properties, red clover also has dietary and feed-technological drawbacks: it is poorly resistant to treading and it is not very 
palatable; it disappears from fallows in 2-3 years and the oppressional losses of dried red clover are great. Partly for these reasons attempts have been made to experiment with new legume varieties suitable for the Finnish climatic conditions which might have a positive effect on the fodder quality and palatability. These plants include white clover (Trifolium repens), alfalfa (Medicago sativa) and goat's rue (Galega orientalis). At present, their adaptability to the Finnish conditions is experimented at agricultural research stations. In this context, it has been considered justified to also examine their content of phytoestrogens and estrogenic effects on rats.

\section{Material and methods}

\section{Experimental}

Samples of white clover, alfalfa and goat's rue were collected during the summer of 1991 from five agricultural research stations in different parts of Finland. There were four white clover (Trifolium repens) varieties: 'Undrom', 'Jögeva', 'Sandra' and 'Tammisto'. Samples of 'Undrom' were collected from the South Savo, Karelia, Kainuu and North Ostrobothnia Research Stations, while samples of 'Jögeva', 'Sandra' and 'Tammisto' were collected from the South Savo Research Station. Samples of goat's rue (Galega orientalis) were collected from the Karelia and Sata-Häme Research Stations and those of variety 'Jokioinen' of alfalfa (Medicago sativa) from the Sata-Häme Research Station. Fertilization was very similar in all the research stations.

During the growing period samples were collected, as a rule, mainly four times: twice from the spring growth (white clover at the pasture and silage stage, alfalfa and goat's rue at the bud and early blossom stages) and twice from the aftermath.

As far as possible, the samples were collected at the same stage of development at all research stations. Samples from the second aftermath of white clover were obtained only from the South Savo Research Station, but even there the growth of clover was poor.
The samples consisted of the entire aboveground part of the plant. The samples were ground in a meat chopper immediately after cutting. Thereafter they were allowed to stand for $30 \mathrm{~min}$ at $+37^{\circ} \mathrm{C}$ for the conjugated phytoestrogens to hydrolyse (FranCIS and MiLlington 1965a) before mixing in absolute ethanol. The samples were then stored in a refrigerator for closer chemical analyses and biological studies.

Studies conducted on subterranean clover have revealed that chrushing leaf tissue releases glucosides to free isoflavones (aglucones) through enzyme hydrolysis (BECK 1964, FRANCIS and MILLINGTON 1965b). Accordingly, when different parts of red clover are milled, enough enzyme ( $\beta$ glucosidase) was released from every part of the plant (stems not included) to allow complete hydrolysis (MCMURRAY et al. 1986).

The adequacy of the hydrolysation method (maceration and incubation for $30 \mathrm{~min}$ at $37^{\circ} \mathrm{C}$ ) was established in tests with red and white clover, in which the results of this method and acid hydrolysis were compared (Table 1).

\section{Chemical analyses}

The method described earlier (KALLELA and SAASTAMOINEN 1978) was adapted for this study as follows:

The plant samples warmed up at room temperature ( $50 \mathrm{~g}$ in absolute ethanol) were mixed intensely for $5 \mathrm{~min}$. The procedure was repeated the next day whereafter the samples were filtered through a Büchner funnel. The filtrate was evaporated using a vacuum evaporator $\left(+40^{\circ} \mathrm{C}\right)$ to reach $100 \mathrm{ml}$. An aliquot was diluted and filtered through an Acrodisc CR filter (Gelman) before high performance liquid chromatography (HPLC).

Daidzein, genistein, formononetin and biochanin-A were determined using a UV detector, and coumestrol was determined by fluorometry. The liquid chromatograph used was a Hewlett Packard 1050 chromatograph provided with an automatic sampler and a UV detector. The fluorometer was a Perkin Elmer LS-4. A Windowsbased Chem Station program of Hewlett Packard in 
Table 1. A comparison between the amounts of isoflavones after the present hydrolysis method and hydrochloric acid hydrolysis.

\begin{tabular}{|c|c|c|c|c|c|c|c|}
\hline \multirow[t]{2}{*}{ Species } & \multirow{2}{*}{$\begin{array}{l}\text { Date of } \\
\text { sample } \\
\text { collection }\end{array}$} & \multirow[t]{2}{*}{ Treatment } & \multicolumn{5}{|c|}{ Isoflavones $\%$ in DM } \\
\hline & & & Daidzein & Genistein & $\begin{array}{l}\text { Formo- } \\
\text { nonetin }\end{array}$ & Bioch.-A. & Total \\
\hline \multicolumn{8}{|l|}{ Red clover } \\
\hline \multirow[t]{3}{*}{ Sample 1} & 1.7 .92 & A & 0.024 & 0.076 & 0.214 & 0.828 & 1.142 \\
\hline & & $\mathrm{A}+\mathrm{B}$ & 0.028 & 0.081 & 0.252 & 0.926 & 1.286 \\
\hline & & $A+C$ & 0.024 & 0.074 & 0.245 & 0.866 & 1.209 \\
\hline \multirow[t]{3}{*}{ Sample 2} & 1.7 .92 & A & 0.025 & 0.084 & 0.203 & 0.888 & 1.199 \\
\hline & & $\mathbf{A}+\mathbf{B}$ & 0.024 & 0.083 & 0.212 & 0.863 & 1.182 \\
\hline & & $A+C$ & 0.028 & 0.076 & 0.224 & 0.858 & 1.206 \\
\hline \multicolumn{8}{|l|}{ White clover } \\
\hline \multirow[t]{2}{*}{ Sample 1} & 7.6 .93 & A & 0.001 & 0.002 & 0.014 & 0.006 & 0.022 \\
\hline & & $A+D$ & 0.000 & 0.002 & 0.015 & 0.004 & 0.022 \\
\hline
\end{tabular}

$\mathrm{A}=$ maceration $+30 \mathrm{~min} 37^{\circ} \mathrm{C}$
$\mathrm{B}=4.6 \mathrm{gDM},+80^{\circ}, 2 \mathrm{~h}$ (reflux) $4-\mathrm{mol} \mathrm{HCL} 1 \mathrm{ml}$ in $30 \mathrm{ml}$ alcohol
$\mathrm{C}=4.6 \mathrm{gDM}+80^{\circ}, 2 \mathrm{~h}$ (reflux) $4-\mathrm{mol} \mathrm{HCL} 10 \mathrm{ml}$ in $30 \mathrm{ml}$ alcohol
$\mathrm{D}=4.0 \mathrm{gDM},+75^{\circ}, 1 \mathrm{~h}$ (reflux) $25 \% \mathrm{HCL} 10 \mathrm{ml}$ in $80 \mathrm{ml}$ alcohol

a 486 computer was used for recording and calculation of the results of samples. The conditions were as follows: column Lichrosorb $100 \mathrm{RP}-185 \mu \mathrm{m}$ $250 \times 4 \mathrm{~mm}$ Hewlett Packard, flow rate $1 \mathrm{ml} / \mathrm{min}$, acetonitrile-water solution, initially $40 \%$, after 5 $\min 70 \%$, after $8.5 \mathrm{~min} 80 \%$ and after $9 \mathrm{~min} 100 \%$ to complete $15 \mathrm{~min}$, was used as mobile phase. The apparatus was stabilised for $7 \mathrm{~min}$ with $40 \%$ acetonitrile before each run. UV-254/nm; fluorometer ex $304 \mathrm{~nm}$, em $454 \mathrm{~nm}$. The following commercial preparations were used as standards: daidzein and formononetin (K \& K Laboratories ICN, USA), genistein (Sigma Chemical CO, USA) and biochanin-A (Aldrich-Chemie, Germany). Standards were diluted to absolute alcohol concentrations of $1-20 \mu \mathrm{g} / \mathrm{ml}$. The injection used was $20 \mu \mathrm{l}$, while on the fluorometer it was $10 \mu \mathrm{l}$ or less.

\section{Biological studies}

The studies were conducted using the method described earlier (KALLELA 1975) with the amount of extract fed to the rats equalling $3 \mathrm{~g}$ of plant dry matter per day. Uterine weight was used as the indicator of the effect of the treatment.
The extract added to the feed of the test rats was prepared based on an earlier study (KALLELA 1964) as follows: The plant samples were cooked in ethanol three times: for $30 \mathrm{~min}, 1 \mathrm{~h}$ and $15 \mathrm{~min}$, and filtered through a Büchner funnel. The ethanol filtrates were pooled and ethanol was evaporated at $+40^{\circ} \mathrm{C}$ using a vacuum evaporator. At the end of evaporation, some (approx. $10 \mathrm{ml}$ ) distilled water was added and evaporation was continued until the water started to distil over. The water residue was transferred with the distilled water and diethyl ether (ca. $40 \mathrm{ml}$ and $250 \mathrm{ml}$ in small doses, respectively) into a separating funnel which was shaken intensely for $5 \mathrm{~min}$, allowed to stand for $30 \mathrm{~min}$ and reshaken for $5 \mathrm{~min}$. After the different layers had separated, the ether extract was collected. The water residue was treated in the same way three more times. The ether extracts were pooled and washed with due care in the separation funnel, shaking with a small amount of water (ca. $50 \mathrm{ml}$ ). Finally the ether extract was evaporated to reach $500 \mathrm{ml}$ using a vacuum evaporator. The extract was added to the feed of the test rats at the calculated doses from which ether was evaporated in a fume hood.

HPLC analyses were conducted on the phytoestrogen concentration of the extracts. An aliquot of 
Table 2. The comparison between HPLC results of phytoestrogens in alcohol and ether extracts.

\begin{tabular}{|c|c|c|c|c|}
\hline \multirow[t]{2}{*}{ Research station } & \multirow[t]{2}{*}{ Species and variety } & \multirow{2}{*}{$\begin{array}{l}\text { Date of sample } \\
\text { collection }\end{array}$} & \multicolumn{2}{|c|}{ Isoflavones $\%$ in DM } \\
\hline & & & Alchol extract & Ether extract \\
\hline \multirow[t]{16}{*}{ South-Savo } & White clover, Jögeva & 17.6 & 0.018 & 0.021 \\
\hline & & 4.7 & 0.019 & 0.020 \\
\hline & & 6.8 & 0.020 & 0.024 \\
\hline & & 2.9 & 0.023 & 0.034 \\
\hline & White clover, Sandra & 17.6 & 0.020 & 0.024 \\
\hline & & 4.7 & 0.019 & 0.020 \\
\hline & & 6.8 & 0.018 & 0.022 \\
\hline & White clover, Tammisto & 17.6 & 0.021 & 0.025 \\
\hline & & 4.7 & 0.019 & 0.021 \\
\hline & & 6.8 & 0.022 & 0.028 \\
\hline & & 2.9 & 0.034 & 0.038 \\
\hline & White clover, Undrom & 17.6 & 0.020 & 0.026 \\
\hline & & 4.7 & 0.023 & 0.027 \\
\hline & & 6.8 & 0.024 & 0.024 \\
\hline & & 2.9 & 0.029 & 0.036 \\
\hline & & \multicolumn{3}{|c|}{ Coumestrol ppm in DM } \\
\hline \multirow[t]{4}{*}{ Sata Häme } & Alfalfa, Tammisto & 17.6 & 33.7 & 34.5 \\
\hline & & 27.6 & 64.8 & 71.6 \\
\hline & & 1.8 & 25.3 & 18.9 \\
\hline & & 12.8 & $*$ & 63.0 \\
\hline
\end{tabular}

* analysis unsuccesful

ether extract was evaporated in a stream of nitrogen $\left(+40^{\circ} \mathrm{C}\right)$ to dryness and the residue was dissolved in an equal volume of ethanol. The sample was diluted and filtered before HPLC analysis. The concentrations parallelled those observed in chemical studies (Table 2).

\section{Results}

The study of the phytoestrogen content and estrogenic effect was negative for goat's rue. Insignificant amounts of formononetin and biochanin-A were observed only in the early spring samples collected at the Karelia Research Station, and signs of coumestrol were observed in the early spring and late autumn samples of the Sata-Häme Research Station. They had no effect on the weight of the rat uterus. Alfalfa showed estrogenic activity which was attributable only to coumestrol (Table 3 ). The quantities of estrogenic isoflavones, formononetin $(90-95 \%)$ and genistein $(5-10 \%)$ discovered in the
Table 3. Phytoestrogen content of alfalfa (Medicago sativa) and the effects on the weight of immature rat uterus. Variety "Jokioinen", Sata-Häme Research Station.

$\begin{array}{ll}\text { Biological study } & \\ \text { Duration of the experiment } & 5 \text { days } \\ \text { Experimental extract } & 3 \mathrm{~g} \mathrm{DM} / \text { day } \\ \text { Rats/test group } & 5 \text { rats } \\ \text { Rats/control group } & 8 \text { rats, uterine weight } \\ & 21.0 \pm 2.0 \mathrm{mg}\end{array}$

\begin{tabular}{lccc} 
Growth stage & $\begin{array}{c}\text { Date of } \\
\text { sample } \\
\text { collection }\end{array}$ & $\begin{array}{c}\text { Coumestrol } \\
\text { ppm in DM }\end{array}$ & $\begin{array}{c}\text { Increase } \\
\text { in weight } \\
\text { of uterus mg }\end{array}$ \\
\hline Bud stage' & 17.6 & 33.7 & $+21.2^{* * *}$ \\
Early blossom & 27.6 & 64.8 & $+57.9^{* * *}$ \\
First aftermath & 1.8 & 25.3 & $+19.3^{* * *}$ \\
Second aftermath & 12.8 & $63.0^{2}$ & $+46.2^{* * *}$ \\
\hline
\end{tabular}

1 small amount of formononetin and signs of biochanin-A in samples of bud stage

${ }^{2}$ HPLC result of ether extract

$* * *=\mathrm{P}<0.001$

white clover varieties were small. In the main part of the material the amount of daidzein and bio- 
Table 4. Phytoestrogen content of white clover and the effects on the weight of immature rat uterus

\begin{tabular}{|c|c|c|c|c|c|c|}
\hline \multicolumn{2}{|c|}{$\begin{array}{l}\text { Duration of the experiment } \\
\text { Experimental extract } \\
\text { Rats/test groups } \\
\text { Rats/control group }\end{array}$} & \multicolumn{5}{|c|}{$\begin{array}{l}5 \text { days } \\
3 \mathrm{~g} \mathrm{DM} / \text { day } \\
5 \text { rats } \\
8 \text { rats; uterine weight } 21.0 \pm 2.0 \mathrm{mg}\end{array}$} \\
\hline Variety & $\begin{array}{l}\text { Research } \\
\text { station }\end{array}$ & $\begin{array}{l}\text { Growth } \\
\text { stage }\end{array}$ & $\begin{array}{l}\text { Date of } \\
\text { sample } \\
\text { collection }\end{array}$ & $\begin{array}{l}\text { Isoflavones } \\
\% \text { in DM }\end{array}$ & $\begin{array}{l}\text { Coumestrol } \\
\mathrm{ppm} \text { in DM }\end{array}$ & $\begin{array}{l}\text { Increase in } \\
\text { weight of } \\
\text { uterus mg }\end{array}$ \\
\hline Jögeva & South Savo & $\begin{array}{l}1 \\
2 \\
3 \\
4\end{array}$ & $\begin{array}{r}17.6 \\
4.7 \\
6.8 \\
2.9\end{array}$ & $\begin{array}{l}0.02 \\
0.02 \\
0.02 \\
0.02\end{array}$ & $\begin{array}{l}0^{*} \\
0^{*} \\
0^{*} \\
0^{*}\end{array}$ & $\begin{array}{l}+18.8^{* *} \\
+21.0^{* * *} \\
+8.6^{* *} \\
+31.1^{* * *}\end{array}$ \\
\hline Sandra & South Savo & $\begin{array}{l}1 \\
2 \\
3 \\
4\end{array}$ & $\begin{array}{r}17.6 \\
4.7 \\
6.8 \\
2.9\end{array}$ & $\begin{array}{l}0.02 \\
0.02 \\
0.02 \\
0.03\end{array}$ & $\begin{array}{l}0^{*} \\
0^{*} \\
6.8 \\
0^{*}\end{array}$ & $\begin{array}{l}+15.8^{* *} \\
+15.0^{* * *} \\
+17.5^{* * *} \\
\quad \text { n.a. }\end{array}$ \\
\hline Tammisto & South Savo & $\begin{array}{l}1 \\
2 \\
3 \\
4\end{array}$ & $\begin{array}{r}17.6 \\
4.7 \\
6.8 \\
2.9\end{array}$ & $\begin{array}{l}0.02 \\
0.02 \\
0.02 \\
0.03\end{array}$ & $\begin{array}{l}0^{*} \\
0^{*} \\
0^{*} \\
8.9\end{array}$ & $\begin{array}{l}+18.9^{* * *} \\
+17.5^{* * *} \\
+15.6^{* * *} \\
+31.7^{* * *}\end{array}$ \\
\hline Undrom & South Savo & $\begin{array}{l}1 \\
2 \\
3 \\
4\end{array}$ & $\begin{array}{r}17.6 \\
4.7 \\
6.8 \\
2.9\end{array}$ & $\begin{array}{l}0.02 \\
0.02 \\
0.02 \\
0.03\end{array}$ & $\begin{array}{l}0^{*} \\
0^{*} \\
0^{*} \\
5.9\end{array}$ & $\begin{array}{l}+8.6^{* * *} \\
+17.3^{* * *} \\
+20.6^{* * *} \\
+45.0^{* * *}\end{array}$ \\
\hline Undrom & Karelia & $\begin{array}{l}1 \\
2 \\
3\end{array}$ & $\begin{array}{r}19.6 \\
4.7 \\
20.8\end{array}$ & $\begin{array}{l}0.06 \\
0.03 \\
0.04\end{array}$ & $\begin{array}{l}5.8 \\
2.2 \\
1.8\end{array}$ & $\begin{array}{l}\text { n.a. } \\
\text { n.a. } \\
\text { n.a. }\end{array}$ \\
\hline Undrom & Kainuu & $\begin{array}{l}1 \\
2 \\
3\end{array}$ & $\begin{array}{r}24.6 \\
9.7 \\
9.8\end{array}$ & $\begin{array}{l}0.04 \\
0.03 \\
0.04\end{array}$ & $\begin{array}{l}2.8 \\
1.6 \\
0^{*}\end{array}$ & $\begin{array}{l}\text { n.a. } \\
\text { n.a. } \\
\text { n.a. }\end{array}$ \\
\hline Undrom & N. Ostrabothnia & $\begin{array}{l}1 \\
2 \\
3\end{array}$ & $\begin{array}{r}25.6 \\
9.7 \\
20.8\end{array}$ & $\begin{array}{l}0.01 \\
0.02 \\
0.03\end{array}$ & $\begin{array}{l}0 * \\
4.2 \\
8.7\end{array}$ & $\begin{array}{l}\text { n.a. } \\
\text { n.a. } \\
\text { n.a. }\end{array}$ \\
\hline
\end{tabular}

1 = pasture stage 2 = silage stage $3=$ first aftermath $4=$ second aftermath

$* *=\mathrm{P}<0.01^{* * * *}=\mathrm{P}<0.001$

$0^{*}=$ less than $1 \mathrm{ppm}$ (limit of the method) n.a. $=$ not analyzed

chanin-A was under the detection limit. Also small quantities of coumestrol were found, but it was not recovered in all samples. The effect of white clover samples on the weight of the rat uterus was, however, clearly positive (Table 4).

\section{Discussion}

The most important Finnish legume used for fodder today is red clover. Its estrogenic effect and factors affecting it have been studied in Finland and in other countries. According to KALLELA (1964), PETtERSON et al. (1984) and KALLELA et al. (1987), all the red clover varieties studied in the Nordic countries contain estrogenic isoflavones, especially formononetin. There are, however, clear differences between varieties. It has been observed also that the growth stage and the temperature affect the quantity of phytoestrogens. They are formed most abundantly in the spring during the rapid growth period or in the autumn in abundant aftermath (KALlela et al. 1987). A cool weather during the growing season increases the amounts of phytoes- 
trogens (PetTersson et al. 1984, MCMURRAY et al. 1986). A clear difference was observed in the phytoestrogen concentrations of red clover varieties between North Finland and South Finland (KALLELA et al. 1988). The amount of nutrients also have an effect. The formononetin concentration of red clover is higher in a phosphorus-poor soil than in a soil fertilized with phosphorus (MCMURRAY et al. 1986). It has also been observed that with increasing nitrogen doses the phytoestrogen concentration and raw protein concentrations in red clover decrease (KALLELA et al. 1987). The possible effect of a number of factors such as soil and rain has not yet been studied as far as we know.

The information obtained mainly from red clover studies formed the basis for planning the phytoestrogen study of new legumes. Goat's rue (Galega orientalis), alfalfa (Medicago sativa) and white clover (Trifolium repens), which were test cultivated at research stations in different parts of Finland, were taken as the objects of study.

\section{Goat's rue}

Of the plants investigated, goat's rue did not contain any known phytoestrogens. Only minor signs of isoflavones (Karelia Research Station) and coumestrol (Sata-Häme Research Station) were observed in the plant samples of early spring and late autumn. The biological study of the effect of phytoestrogens on the weight of the rat uterus was completely negative. As far as we know, there are no studies or information in the literature concerning the estrogenic properties of goat's rue.

\section{Alfalfa}

The estrogenic efficacy of alfalfa was studied in the early days of phytoestrogen research in Finland. The criteria then were the changes in the weight of the uterus and vaginal smear of ovariectomized rats (KALlela 1964). Of the varieties then studied, 'Rhizoma' had an obvious effect, 'Normad' a smaller effect.

According to the present HPLC study, the estro- genic effect of alfalfa is most obviously attributable to coumestrol. The samples contained very small quantities of estrogenic isoflavones (formononetin and biochanin-A), whereas the coumestrol content was remarkably high in the spring and especially in the autumn.

According to the present biological study, the estrogenic effect of alfalfa was also quite obvious. No such consistency as in the red clover studies (KALLELA et al. 1987) - high estrogen concentrations in early spring, a clear decrease by midsummer, and an increase again in aftermath - could, however, be observed in the chemical and biological studies of alfalfa.

Coumestrol is known to be about 30 times more effective than genistein in mice (BECK 1964), and to cause estrogen-related disorders in animals (BICKOFF et al. 1969). In addition, coumestrol seems to have a cumulative effect. Consequently, even quite small amounts ( $25 \mathrm{ppm})$ in the fodder may have a negative effect and reduce the fertility of sheep (SMITH et al. 1979). WHITTEN et al. 1992 have found that coumestrol induces uterine growth in rats over a 90 -h period at a dietary concentration of $0.01-0.1 \%$. Lower doses not active over this period were active when provided over a longer period. A coumestrol concentration as low as $0.005 \%$ induced uterine enlargement if the diet was provided over $180 \mathrm{~h}$.

Coumestrol has been observed to accumulate in alfalfa following insect or fungal attack (LOPER 1968). According to some studies, the coumestrol concentration of alfalfa is a consequence of fungal diseases (SMITH et al. 1979). Healthy plants only contain very small quantities of coumestrol (WONG et al. 1971). There are, however, differences between varieties (BICKOFF et al. 1967, WONG et al. 1971). In the samples investigated now there were no indications of fungal or other diseases.

\section{White clover}

There are only few observations on the estrogenic disorders caused by white clover in domestic animals (WRIGHT 1960). Like in alfalfa, the most active phytoestrogen in white clover is coumestrol 
which may increase considerably as a result of fungal diseases, or it may be solely attributable to fungal diseases (WONG et al. 1971, SHUTT 1976).

According to the present HPLC study, the phytoestrogen concentrations of all white clover varieties were small at all research stations. The samples contained estrogenic isoflavones only $0.02-0.06 \%$, whereas red clover may contain more than $2 \%$. Also coumestrol was found in small quantities and inconsistently.

A biological study of the efficacy of the estrogenic effect of white clover varieties was only conducted from the clover samples grown at the South Savo Research Station. The result was clearly positive, but inconsistent with the results of the chemical study. It is obvious that a small quantity of isoflavones (in rats also almost inactive formononetin) does not explain the increased weight of the uterus. The slightly elevated coumestrol content in the late autumn samples of varieties 'Tammisto' and 'Undrom' could have been due to the colder weather in the autumn and may to some extent have affected the results of the biological studies. The cold autumn weather and especially the night frosts may increase considerably coumestrol concentrations like phytoestrogen concentrations in general (PETTERSSON et al. 1984). Small and inconsistent coumestrol concentrations do not, however, explain the obvious discrepancy between the results of the biological and chemical studies. In fact, there were apparently other substances increasing the estrogenic potency which were shown in the biological studies but not in the chemical studies. Apparently these are primarily substances of the coumarin group which might explain the inconsistent results of alfalfa and especially of white clover. Their contribution should be studied further in the future.

Acknowledgements. We wish to thank the researchers at Karelia (P. Virkajärvi), Kainuu (E. Kemppainen), North Ostrobothnia (H. Hakkola), Sata-Häme (T. Kangasmäki) and South Savo (P. Kivijärvi, P. Nykänen-Kurki) Research Stations of the Agricultural Research Centre of Finland for sampling and conserving of grass samples.

\section{References}

Adlercreutz, H., Honjo, H., Higashi, A., Fotsis, T., HÄmÄläınen, E., Hasegawa, T. \& OKadA, H. 1991. Urinary excretion of lignans and isoflavonoid phytoestrogens in Japanese men and women consuming a traditionel Japanese diet. Am. J. Clinl. Nutr. 54: 1093-1100.

BECK, A.B. 1964. The oestrogenic isoflavones of subterranean clover. Aust. J. Agric. Res. 15:223-230

Bennetts, H.W., Underwood, E.J. \& Shier, F.L. 1946. A breeding problem of sheep in the south-west division of western Australia. Aust. Vet. J. 22:2

Bickoff, E.M., Loper, G.M., Hanson, C.H., Graham, J.H., WrTt, S.C. \& SPENCER, R.R. 1967. Effect of common leafspot on coumestans and flavones in alfalfa. Crop Science 7: 260-261

—, SPEnCER, R.R., Witt, S.C \& KnUCKLES, B.E. 1969. Studies on the chemical and biological properties of coumestrol and related compounds. United States Department of Agriculture. Agricultural Research service. Technical Bulletin No. 1408: 1-95.

Francis, C.M. \& Mil.ıngton, A.J. 1965a. Varietal variation in the isoflavone content of subterranean clover: its estimation by a microtechnique. Aust. J. Agric. Res. 16: 557-564.

— \& Mil..ington, A.J. 1965b. Isoflavone mutations in subterranean clover. I. Their production characteristics and inheritance. Aust. J. Agric. Res. 16:713-731.
KALLELA, K. 1964. The incidence of plant oestrogens in Finnish pasture and fodder plants with special reference to their possible effects in cases of sterility in ruminants. Thesis, Helsinki. 132 p.

-1975 . The effect of red clover silage. Nord. Vet. -Med. 27: 562-569.

-, Heinonen, K. \& Saloniemi, H. 1984. Plant oestrogens: the cause of decreased fertility in cows. A case report. Nord. Vet.-Med. 36: 124-128.

— \& SaAstamoinen, I. 1978. Analysis of plant estrogens in fodder by liquid cromatography. Kemia-Kemi 5: 622623.

-, SaAstamoinen, I. \& Huokuna, E. 1987. Variations in the content of plant oestroegens in red clover - timothy-grass during the growing season. Acta Vet. Scand. 28: 255262.

-, Saastamoinen, I., Huokuna, E. \& Hakkola, H. 1988. Kasviestrogeenipitoisuuden vaihtelut muutamien punaapilalajikkeiden vălillä Pohjois- ja EteläSuomessa, Suom. Eläinlääkäril. 94: 287-291.

LOPER, G. M. 1968. Accumalation of coumestrol in Barrel Medic (Medicago littoralis) Crop Science 8:317-319.

McMurray, C.H., Scott Laidlaw, A. \& McElroy, M. 1986. The effect of plant development and environment of formononetin concentration in red clover. J. Sci. Food. Agric. 37: 333-340. 
Pettersson, H., Holmberg, T., Kiessling, K.-H. \& RutQvist, L. 1984. Växtöstrogener i foder och reproduktionsstörningar hos idisslare. Svensk. Vet. Tidsskrift 36: 677-682.

ReFsDAL, A.O. 1976. Fertiliteten hos kyr i relasjon til forbruk av sufor og tort stråfor i de olike fylke i Norge. Norsk Vet. Tidsskrift 88: 597-604.

Rose, D.P. 1992. Dietary fiber, phytoestrogens, and breast cancer. Nutrition 8: 47-51.

Smith, J.F., JagusCh, K.T., BRUnSWiCK, L.F.C. \& Kelly, R.W. 1979. Coumestans in lucerne and ovulation in ewes. N.Z. Agric. Res. 22:411-416,

SHutr, D.A. 1976. The effects of plant oestrogens on animal production. Endeavour 35: 110-113.

Whitten, P.L., Russell, E. \& Naftoli, F. 1992. Effects of a normal human- concentration phytooestrogen diet on rat uterine growth. Steroids 57: 98-106.
Wong, E., Flux, D.S. \& Latch, G.C.M. 1971. The oestrogenic activity of white clover (Trifolium repens L.) N.Z. J. Agric. Res. 14: 639-645.

WRIGHT, P.A. 1960. Infertility in rabbits induced by feeding Ladino clover. Proc. Soc. exp. Biol. Med. 105: 428-430.

Manuscript received February 1993

Hannu Saloniemi

Kaarlo Kallela

Ilkka Saastamoinen

College of Veterinary Medicine

Department of Basic Veterinary Medicine

Section of Animal Hygiene

Box 6

FIN-00581 Helsinki, Finland

\title{
SELOSTUS
}

\section{Vuohenherneen (Calega orientalis), sinimailasen (Medicago sativa) ja valkoapilan (Trifolium repens) kasviestrogeenipitoisuus}

\author{
HannU Saloniemi, KaARlo Kallela ja ILKKa SaAstamoinen \\ Eläinläăketieteellinen korkeakoulu
}

Tutkimuksissa selvitettiin Maatalouden tutkimuskeskuksen tutkimusasemilla viljelykokeissa olevien vuohenherneen (Galega orientalis Lam.), sinimailasen (Medicago sativa L.) ja valkoapilan (Trifolium repens $\mathrm{L}$.) kasviestrogeenipitoisuutta. Tutkimuksen mukaan vuohenherne ei aivan vähäisiă määriä lukuunottamatta sisältänyt tunnettuja kasviestrogeeneja. Myöskäăn biologisissa kokeissa sillä ei ollut estrogeenista vaikutusta. Sinimailasen estrogeeninen teho johtui ilmeisesti kasvin coumestrolista, jota näytteissä oli 34-65 ppm. Kaikkien valkoapilalajikkeiden estrogeenisten isoflavonien ja coumestrolin määrä oli hyvin pieni, eikä se riitä selvittämään biologisessa kokeissa immaturen rotan kohdun painossa todettua lisäystä. 